\title{
STUDENTS' ANXIETY IN SPEAKING ENGLISH AT SECOND SEMESTER OF ENGLISH STUDY PROGRAM AT UNIVERSITY OF PASIR PENGARAIAN
}

\author{
Rahmad Kurniadi ${ }^{1}$, Evi Kasyulita ${ }^{2}$ \\ English Study Program, University of Pasir Pengaraian \\ Rahmadkurniadi0@gmail.com,eviyulita23@yahoo.com,
}

\begin{abstract}
Anxiety is uncomfortable feeling that someone feels in facing any situation. Anxiety is common problem in speaking especially to learners. The purpose of the research was to find out the factors and the types of students' anxiety in speaking at second semester students of English study program at University of Pasir Pengaraian. This research was design a descriptive qualitative research and instrument that the researcher used in collecting the data is questionnaire. The sample of the research were 15 students. The finding result of the research showed, there were 14 students classified into state anxiety, and 1 students classified into trait anxiety. So the most of second semester students were classified into state anxiety. This result was taken from open-ended questions.
\end{abstract}

Keywords: Anxiety, Speaking, State anxiety, Trait anxiety

\section{INTRODUCTION}

Language is one of the most important things in communication and it is used as a toll of communication among the nations in all over the world. As an international language, English is very important and has many interrelationships with various aspects of life owned by human being. In Indonesia, English considered as the first foreign language and taught formally from elementary school up to the university level. But, there were many problems in process of teaching and learning this language. One of that many problems is student's anxiety. In psychology, Alrabai (2014) states that anxiety is a state characterized by the sensation of vague fear, nervousness, discomfort, and apprehension that is not linked to a specific cause or situation. Then, it can be assumed that anxiety related to fear, panic, and worry 
of person. Awan et al. (2010: 34) state that a feeling of nervousness associated with language learning is termed as language anxiety. Other study found that there is a negative correlation between students' Achievement and their anxiety. Moreover, MacIntyre and Gardner (1991) also state that anxiety affects at least five domains in second/foreign language learning and performance: academically, Socially, Cognitively, personally, and communication output. From this reason, anxiety is believed to be as individual characteristics which are very potential to affect students' success in English learning.

As in English study program at University of Pasir Pengaraian, students are rarely speaking in teaching and learning process. They speak when lecturer asked question, and when it is necessary. The researcher's experience is also evident that most students experience anxiety in speaking English, this is encountered by researcher when learning in second semester view years ago. In addition, the students have not dared to speak English. However, they can write sentences in English, it's just that they were afraid of being wrong when speaking English.

In that case, the researcher intended to took up the problem, through research entitled: Student's Speaking Anxiety at Second semester of English study Program in University of Pasir Pengaraian

\section{REVIEW OF THE RELATED THEORIES}

There are several definitions of anxiety by experts. According to Carlson and Buskist (1997), anxiety is "a sense of apprehension or doom that is accompanied by certain physiological reactions, such as accelerated heart rate, sweaty palms, and tightness in the stomach. Furthermore, "anxiety arises as a response to a particular situation. Passer and Smith (2010) define anxiety as a state of tension and apprehension as a natural response to perceived threat.It means that people are naturally feels anxious when they are threatened. While according to Ormrod (2011), anxiety is a feeling of uneasiness and apprehension concerning a situation with an uncertain outcome.

According to Barlow (2002), Anxiety responses consist of emotional 
component, feeling of tension; cognitive component, worry; physiological responses, increased heart rate and blood pressure; and behavioral responses avoidance of certain situations. From the definition explained above, it can be concluded that anxiety is a feeling of being threatened, of apprehension, tension, and worry as a response to a particular situation or something that might happen in the future. Two approaches to the study of anxiety have been identified as the state and trait anxiety (MacIntyre and Gardner, 1991). According to Ormrod (2011), "state anxiety is temporary feeling of anxiety elicited by a threatening situation." It is anxiousness or tension at a particular moment in response to some external stimulus. This type of anxiety arises in a particular situation or in stressful event and hence is not permanent. In other words, it is a situational anxious feeling that disappears when threatening situation goes away. Trait anxiety is defined as the individual's likelihood of becoming anxious in any situation (Spielberger, 1983). Spielberger has emphasized the necessity of distinguishing trait anxiety from state anxiety. Trait anxiety refers to a relatively stable emotional state that an individual experiences more frequently or more intensely than most people on the average and is part of the individual's personality. According to Goldberg (1993, cited in MacIntyre, 1999), people with high levels of trait anxiety are typically nervous and they lack emotional stability. An individual with a high level of trait anxiety shows tendencies to become apprehensive across a number of different situations as a result of generally regarding these situations as more threatening than they actually are (Spielberger, 1983). On the other hand, a person with a low trait anxiety is an emotionally stable, calm and relaxed person. According to Ormrod (2011), "trait anxiety is pattern of responding with anxiety even in nonthreatening situations." Such anxiety is a part of a person's character. People with trait anxiety tend to worry more than most people and feel inappropriately threatened by several things in the environment. In other words, trait anxiety is the tendency of a person to be nervous or feel anxious irrespectively of the situation he/ she exposed to. 


\section{RESEARCH METHODOLOGY}

The research categorized into descriptive qualitative research. According to Issac and Michael (1981:46), descriptive research is used in the literal sense of describing situations or events. Descriptive research was research that involves a collection of techniques used to specify, delineate or describe the data naturally occurring phenomena without experimental manipulation. The purpose of descriptive qualitative research was to describe the data systematically the facts and characteristics of area of interest factually and accurately (Isaac and Michael, 1981:42). The researcher chose descriptive qualitative case study to explore the factors and types of anxiety, regarding EFL students' speaking anxiety as well as in teaching learning process due to the fact that this research project involves a group of ESL students, their social situation and interactions. It matches the intent of qualitative research that to understand a particular social situation, event, role, group and interaction (Locke,Spirduso, \&Solverman, 1987).

\section{FINDING AND DISCUSSION}

Based on the data gained and its analysis, it was found the factors and the types of student's anxiety in speaking. It was explained bellow:

Table 1. Types of anxiety

\begin{tabular}{|l|l|c|c|}
\hline No & Types of Anxiety & Total & Students \\
\hline 1 & State anxiety & 14 & $1,2,3,4,5,6,7,9,10,11,12,13,14,15$ \\
\hline 2 & Trait anxiety & 1 & 8 \\
\hline
\end{tabular}

The students were devided into 2 types of anxiety. they were state anxiety and trait anxiety (MacIntyre and Gardner, 1991). Student $1,2,3,4,5,6,7,9,10,11,12,13,14$, and 15 were included into to state anxiety, because based on their answers, they only feel anxious in specific situation and their anxiety do not lasted for long. while student 8 included into trait anxiety because student 8 still feeling anxious even threatening situation were gone. 
Table 2. Factors of anxiety

\begin{tabular}{|l|l|c|l|}
\hline No & Factors of anxiety & Total & \multicolumn{1}{|c|}{ Students } \\
\hline 1 & Negative experience & 10 & $1,2,3,4,6,7,8,9,10,14$ \\
\hline 2 & Irational thinking & 5 & $5,11,12,13,15$ \\
\hline
\end{tabular}

According to Adler and Rodman (1991), there were two factors caused the anxiety, they are negative experience in the past and irrational thinking. Student $1,2,3,4,6,7,8,9,10$, and 14includedinto Negative experience because based on their answers that says they have negative experience in the past. While student $5,11,12,13$, and 15 were included to irrational thinking .

\section{CONCLUSION AND SUGGESTION}

The finding result of the research showed, there were 14 students classified into state anxiety, and 1 student classified into trait anxiety. So, the most of second semester students were classified into state anxiety. There were 10 students included to negative experience factor, and 5 students included to irrational thinking factor. This result was taken from questionnaire. From the questionnaire also showed, most of students at second semester of English Study Program at University of Pasir Pengaraian were feel anxious when speaking English. Some of the reasons were, they were worry about making mistakes, lack of vocabularies, afraid if other students will laugh them, lack of speaking skill, and not confident.

\section{ACKNOWLEDGEMENT}

I would like to say thank you to my advisors Evi Kasyulita, M.Pd and Andri Donal, M.Pd for the time, suggestion, guidance, motivation, support, spirit and help to finish this final assignment. Thank you to gave a knowledge that I do not know before, then now I know.

\section{REFERENCES}

Adler, R.B., and Rodman, G., 1991, Understanding Human Communication, Toronto: Holt Rinehart and Winston.

Alrabai, F. 2014, Motivational Practices in English as a Foreign Language Classes in Saudi Arabia: Theachers Beliefs and Learners Perceptions. Arab World English Journal, 5 (1), 224-246.

Barlow, D. H. (2002). Anxiety an its Disorders: The nature and treatment of anxiety and panic. New York, NY, US: Guilford Press.

Isaac, S., \& Michael, W. B. 1981.Handbook in Research and 
Evaluation.San Diego, California: EdITS Publishers.

MacIntyre, P. D. 1995. How does Anxiety Affect Foreign Language Learning: A Reply to Sparks and Ganschow. The Modern Language Journal.

MacIntyre, P. D. and Gardner, R.C. (1991). Methods and results in the study of anxiety and anguage learning: A review of the literature Language Learning, Google Scholar, 41, 85- 117.

Mischel, W. \& Peak, P. K. (1982). Beyond deja vu in the search for cross- situational consistency. Psychological Review, 89, 730-755.

Omrod, J.E. (2011). Educational Psychology: Developing Learner. Boston: Pearson Education.

Spielberger, C. D. (1983). Manual for the state-trait anxiety inventory. Palo Alto, California: Consulting Psychological Press. 